\title{
Rumen-protected choline: A significance effect on dairy cattle nutrition
}

\author{
G. Jayaprakash ${ }^{1}$, M. Sathiyabarathi ${ }^{2}$, M. Arokia Robert ${ }^{1}$ and T. Tamilmani ${ }^{3}$
}

1. Department of Animal Nutrition, College of Veterinary and Animal Sciences, Kerala Veterinary and Animal Sciences University, Mannuthy, Thrissur - 680 651, Kerala, India; 2. Southern Regional Station, ICAR - National Dairy Research Institute, Adugodi, Bengaluru - 560 030, Karnataka, India; 3. Department of Poultry Science, Indian Veterinary Research Institute, ICAR, Izatnagar - 243 122, Uttar Pradesh, India.

Corresponding author: G. Jayaprakash, e-mail: drgjayaprakash@gmail.com,

MS: drmsathiyabarathi@gmail.com, MAR: arokiarobert@gmail.com, TT: tamilvet3@gmail.com

Received: 14-04-2016, Accepted: 09-07-2016, Published online: 11-08-2016

doi: 10.14202/vetworld.2016.837-841 How to cite this article: Jayaprakash G, Sathiyabarathi M, Robert MA, Tamilmani T (2016) Rumen-protected choline: A significance effect on dairy cattle nutrition, Veterinary World, 9(8): 837-841.

\begin{abstract}
Choline is a vitamin-like substance it has multi-function in animal production, reproduction, and health. The transition period is most crucial stage in lactation cycle of dairy cows due to its association with negative hormonal and energy balances. Unfortunately, unprotected choline easily degrades in the rumen; therefore, choline added to the diet in a rumenprotected form. The use of rumen-protected choline (RPC) is a preventive measurement for the fatty liver syndrome and ketosis; may improve milk production as well as milk composition and reproduction parameters. This review summarizes the effectiveness of RPC on animal production, health, and reproduction.
\end{abstract}

Keywords: choline, dairy cows, health, production, reproduction.

\section{Introduction}

Choline $\left[\left(\mathrm{CH}_{3}\right) 3 \mathrm{~N}+\mathrm{CH}_{2} \mathrm{CH}_{2} \mathrm{OH}\right]$, also called as trimethyl ethanolamine, is a multi-function B-complex vitamin. It is synthesized endogenously, and it is difficult to identify a syndrome in ruminants because of its interrelationship with methionine, vitamin B12, and folic acid. Rumen-protected choline (RPC) acts on several mechanisms; first, it may serve to spare methyl groups. Second, it may serve as the remethylization of homocysteine via its metabolite betaine. Third, it may be spare animal metabolism. It is found in free form in biological tissues and component of lecithin, acetylcholine, plasmalogens, and sphingomyelins. During the transition period, cows may undergo a severe negative energy balance (NEBAL). NEBAL causes several metabolic disorders or disease in dairy cows. Immediate onset of lactation and increased milk production, animal require excess amount of energy. Recent research indicates feed additives, such as RPC, were observed decreases the health disturbances and increases the milk yield. Supplemental choline chloride extensively degraded $(>80 \%)$ by rumen microbial population [1] and not much choline is available for absorption. Therefore, choline must be given in the rumen-protected form [2]. RPC usually supplied as choline chloride covered by a protective layer of the fatty acid matrix; rumen microbes cannot digest fatty acid layer of protected choline. However, the digestive enzyme breaks down the fatty acid in small

Copyright: Jayaprakash, et al. Open Access. This article is distributed under the terms of the Creative Commons Attribution 4.0 International License (http://creativecommons.org/licenses/ by/4.0/), which permits unrestricted use, distribution, and reproduction in any medium, provided you give appropriate credit to the original author(s) and the source, provide a link to the Creative Commons license, and indicate if changes were made. The Creative Commons Public Domain Dedication waiver (http:// creativecommons.org/publicdomain/zero/1.0/) applies to the data made available in this article, unless otherwise stated. intestine and choline is free for absorption. Choline has been observed to increase milk production [3-5]. Moreover, choline supplementation may improve the transport of lipids in the blood to reduce the risk of fatty liver and ketosis [6,7] and decreases the accumulation of non-esterified fatty acid (NEFA) concentration and increased glycogen content of liver [8]. RPC has a positive effect on decreasing hepatic triacylglycerides, and it may involve in increased fatty acid oxidation [6]. Supplementation of RPC to transition dairy cows can alleviate the health disorders, reproductive problems, the incidence of metabolic disorders [5]; an occurrence of ketosis and mastitis [9].

\section{NEFA as an Indicator of NEBAL}

During calving, increased NEFA and beta hydroxyl butyric acid (BHBA) concentration in the blood indicate NEBAL and it leads to reduced milk yield, increased postpartum diseases, and decreased reproductive performance. The presence of NEFA in blood is a direct indicator for NEBAL. In high yielding dairy cows during the transition period, a rapid mobilization of fatty acids from the adipose tissue, resulting in high circulating concentrations of NEFA in the blood stream. Excessive mobilization of fatty acids from adipose tissue indicates that more energy is required than the dietary supplement. In ruminants limited capacities of hepatic fatty acid oxidation and export of very-low density lipoprotein (VLDL) [10]. Therefore, increase uptake of NEFA by the liver can result in the development of fatty liver (hepatic lipidosis caused by increased accumulation of triacylglycerol within liver parenchyma). Triglyceride fatty acids in chylomicrons and lipoprotein called as NEFA. In addition, excessive accumulation of triglyceride in the liver leads to alleviating the capacity of detoxifying ammonia to urea [11] which, in turn, may disturb 
gluconeogenic capacity from propionate, the predominant glucogenic precursor.

\section{Rumen Degradation of Dietary Choline}

Study of unprotected choline in rumen not effective measure by digestibility studies because due to complete or partially degradation by rumen microbes before it even reaches the intestine [3] and difficult to estimate of endogenous choline synthesis in ruminants [12]. Synthetic choline chloride was more degradable than naturally occurring choline in the feed [2]. Sharma and Erdman [13] reported that the percentage of dietary choline and synthetic choline degradation in the rumen varies according to the type of feed (Table-1). Hence, supplementation of unprotected choline (conveniently as it is salt and choline chloride) ineffective way to increase the choline supply. Therefore, the rumen-protected form of choline has been developed to deliver choline with less degradation (Figure-1) to the small intestine for absorption [14]. Choline requirement is still unknown for dairy cows [12]. Rumen protected a form of choline increases the supply of choline to the small intestine with increasing milk yield and milk components or alleviating development of fatty liver syndrome $[4,8,15]$. To avoid ruminal degradation, researchers approached two types of experimental methods for delivering choline directly to the small intestine without ruminal degradation, viz., post-ruminal infusion, choline infused directly through the abomasum; this method was developed before the introduction of rumen protected technology $[1,13]$ and supplementation of choline in the form of rumen protected, many studies have been conducted on efficacy of rumen protected technology (Table-2).

\section{Impact of dry matter intake (DMI)}

RPC supplements could not increase cow's appetite [16]. Many researchers found that RPC did not affect DMI in early lactating dairy cows [16-19].

\section{Impact of choline on digestibility}

Choline supplements increase to produce volatile fatty acid (VFA) acetate and rumen $\mathrm{pH}$ tends to increase digestibility coefficient of nutrients in rumen. Mohsen et al. [9] studied on the digestibility coefficient in Friesian cows supplemented with RPC, which increases DM, organic matter, crude protein, crude fiber, ether extract, and nitrogen free extract significantly. This might be because of RPC enhances the protozoal population in the rumen. In numerous studies, researchers found supplementation of RPC increases the DMI in dairy cows [20]. Contrary to the above findings, some researchers also found that the supplementation of RPC did not change the DMI [6,21]. Supplementation of RPC did not affect DMI before calving, but when supplemented after calving, it tended to increase DMI. It is unknown, the mechanism by which choline might influence DMI [22].
Table-1: Rumen degradability of dietary feed choline and synthetic choline [2].

\begin{tabular}{lc}
\hline Feeds & Rumen degradability (\%) \\
\hline Barley & 79.4 \\
Cottonseed meal & 84.7 \\
Fish meal & 82.9 \\
Soybean meal & 83.8 \\
Choline stearate & 98.0 \\
Choline chloride & 98.6 \\
\hline
\end{tabular}

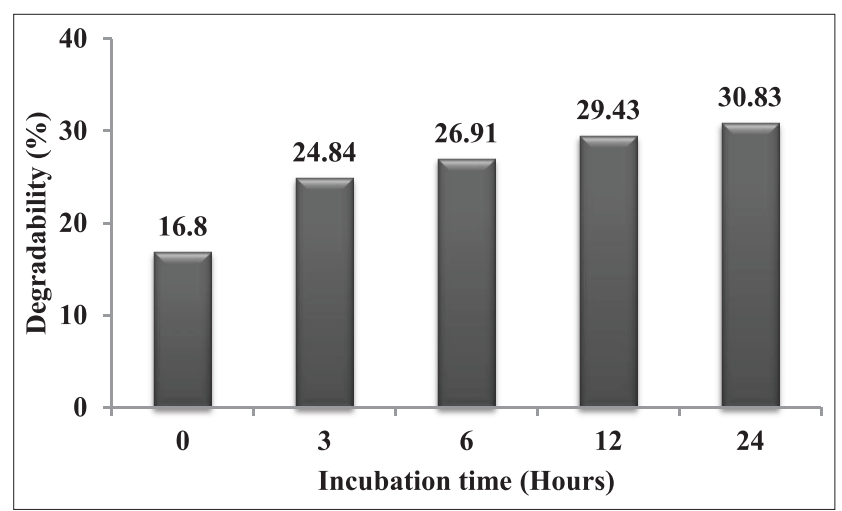

Figure-1: Percent degradability of rumen-protected choline by insacco method [14].

\section{Impact of choline on hematological parameter}

RPC supplemented cows had significantly increased serum cholesterol [20] but reduced plasma cholesterol, triglycerides concentration [9], and glucose $[8,23]$. RPC had no significant effect on the levels of plasma concentration of NEFA, BHBA, and glucose. This might be because of no alteration in the adipose mobilization or BHBA production in the liver by choline supplementation $[8,17,19,23]$. Supplementation of RPC had no significant effect on the plasma glucose, total protein, albumin, globulin, and urea-N in different experimental groups $[17,24]$.

\section{Impact of choline on milk yield}

In an animal production system, the quantity and quality of milk production are the most important traits. Supplementation of RPC increases the milk production for the following reasons, viz., higher digestibility and increased total VFA concentration, decreased $\mathrm{NH}_{3}-\mathrm{N}$, and prevention of metabolic disorders such as ketosis and fatty liver syndrome [9]. Increasing the intestinal supply of choline has improved milk production in lactating dairy cows approximately 7\% over controls [25]. In numerous studies, researchers have been observed a tendency for higher milk yield (Table-3) with the supplementation of RPC $[9,26]$ and fat corrected milk (FCM) [20,22]. In contrast, some researchers could not observe any positive effect on milk production and FCM by supplementation of RPC [24,27,28]. However, supplementation of RPC had no effect on milk yield for the following reasons, viz., the difference in study design such as body condition score [19], parity [18], other supplement diets [5], method of application [29], breed [17], and 
the quantity of supplement, length of the treatment period, and stage of lactation.

\section{Impact of choline on milk composition}

Choline is essential lipotropic agent prevents and corrects excess fat deposition in the liver. Increase effect on milk protein by supplementation of choline due to elevated casein contents. Choline used facilitates phospholipid synthesis may lipid absorption and transport to the mammary gland, thereby favoring milk fat synthesis. Supplementation of RPC significantly increases the milk fat yield, milk protein, lactose, solids not fat (SNF), and total solids $[8,9,21,24,27,30]$. However, some researchers could not observe any significant effect on milk fat yield, milk protein, lactose, SNF, total solids, and milk urea nitrogen concentrations in RPC-supplemented cows compared with control $[8,14,17,24,30,31]$. On the other hand, supplementation RPC has not been positively associated with milk concentrations of lactose and other milk components $[4,17,15]$.

\section{Impact of choline on health and body weight}

In early lactation on dairy animals, the majority of fatty acids secreted by mammary gland and it can increase high animal weight decline, increase the incidence of fatty liver, and increase the chance of subclinical and clinical ketosis $[6,4]$. RPC supplements had weight gain in heifers [32], whereas RPC supplements

Table-2: Description of RPC used in the different studies.

\begin{tabular}{lccc}
\hline Study & $\begin{array}{c}\text { Choline chloride } \\
\text { \% (wt/wt) }\end{array}$ & $\begin{array}{c}\text { Rumen } \\
\text { stability \% }\end{array}$ & References \\
\hline 1 & 25 & $85^{\mathrm{a}}$ & {$[36]$} \\
2 & 25 & $20.4^{\mathrm{b}}$ & {$[37]$} \\
3 & - & $>85^{\mathrm{c}}$ & {$[3]$} \\
4 & 45 & - & {$[7]$} \\
5 & 50 & $50^{\mathrm{d}}$ & {$[38]$} \\
6 & 27.11 & 72.89 & {$[14]$} \\
7 & 18.8 & - & {$[27]$} \\
\hline
\end{tabular}

${ }^{\mathrm{a}}$ In vitro analysis, ${ }^{\mathrm{b}} \mathrm{After} 8 \mathrm{~h}$ in situ incubation in rumen cannulated adult ewes, 'After $48 \mathrm{~h}$ in situ incubation in rumen cannulated adult ewes, ${ }^{\mathrm{d}}$ In vitro analysis. RPC: Rumen protected choline found no effect on body weight [16,30]. During the transition period, accumulation fat in the liver and leads to fatty liver syndrome. Supplementation of $\mathrm{RPC}$ has been found to alleviate the range of hepatic fatty infiltration and increase VLDL transport from liver and prevents accumulation of fat in liver to avoid fatty liver syndrome [30]. RPC supplementation did not show any positive effect in reduction of fever, metritis, and displaced abomasum [33]. However, effectively reduces the incidence of clinical ketosis [34], mastitis, retained fetal membranes, and less morbidity [35]. RPC supplementation could not found any significant differences in body weightamong choline supplemented groups $[8,20,27,30,33,35]$.

\section{Impact on reproductive performances}

During the transition period, excess mobilization of adipose tissue to milk fat synthesis results in increased incidence of reproductive problems. Follicular development is less in during the period of NEBAL meanwhile follicles developed may be less chance of fertile. RPC did not influence the insemination and pregnancy loss [33]. Ardalan et al. [5] noticed a significant effect on service per conception and open days of dairy cows among the treatment groups $(p<0.05)$, but there was no significant effect on days to first estrus and pregnant cows. Guretzky et al. [17] reported that supplemental RPC group had more twinning $(\mathrm{p}=0.07)$ compared to control group.

\section{Conclusion}

During the transition period, RPC supplemented cows change plasma NEFA concentration, increase hepatic fat export, and this may effect decrease the risk for metabolic disorders and increase milk and milk composition.

\section{Authors' Contributions}

GJ conceptualized the concept of this review paper. GJ, MS, MA and TT drafted and edited the manuscript. All authors read and approved the final manuscript.

Table-3: Summary of studies on the impact of supplementation of RPC on milk production and composition on the lactating dairy cow.

\begin{tabular}{|c|c|c|c|c|c|c|}
\hline Lactation stage & $\begin{array}{c}\text { RPC } \\
\text { (g/day) }\end{array}$ & $\begin{array}{c}\text { DMI } \\
\text { (kg/day) }\end{array}$ & $\begin{array}{l}\text { Milk yield } \\
(\mathrm{kg} / \mathrm{day})\end{array}$ & $\begin{array}{l}\text { Fat yield } \\
\text { (g/day) }\end{array}$ & $\begin{array}{c}\text { Protein yield } \\
(\mathrm{g} / \text { day })\end{array}$ & References \\
\hline \multirow[t]{4}{*}{21 days prepartum to 63 days postpartum } & 0 & $12.6-17.8$ & 40.0 & 1593 & 1174 & [8] \\
\hline & 45 & $11.9-18.7$ & 43.3 & 1836 & 1314 & \\
\hline & 60 & $12.8-18.3$ & 39.9 & 1596 & 1206 & \\
\hline & 75 & $12.5-18.8$ & 41.0 & 1763 & 1262 & \\
\hline \multirow{2}{*}{14 days prepartum to 30 days postpartum } & 0 & $11.3-19.4$ & 28.5 & 880 & 868 & [4] \\
\hline & 20 & 11.4-19.9 & 31.4 & 1056 & 966 & \\
\hline \multirow[t]{2}{*}{21 days prepartum to 21 days postpartum } & 0 & $12.0-14.8$ & 29.6 & 1380 & 1050 & [14] \\
\hline & 15 & $12.1-15.7$ & 31.6 & 1460 & 1090 & \\
\hline \multirow[t]{2}{*}{ 21-90 days postpartum } & 0 & 27.9 & 27.9 & 840 & 730 & [18] \\
\hline & 40 & 20.2 & 27.5 & 790 & 740 & \\
\hline \multirow{2}{*}{4 weeks prepartum to 20 weeks postpartum } & 0 & No & 30.71 & 1071 & 1009 & {$[5]$} \\
\hline & 60 & reported & 34.23 & 958 & 902 & \\
\hline
\end{tabular}

RPC: Rumen protected choline, DMI: Dry matter intake 


\section{Acknowledgments}

The first author is thankful to Dr. K. Shyama and Dr. Dinesh Kumar for providing needful facilities. The authors declare that they have no competing interests.

\section{References}

1. Sharma, B.K. and Erdman, R.A. (1989) In vitro degradation of choline from selected feedstuffs and choline supplements. J. Dairy Sci., 72: 2772-2776.

2. Atkins, K.B., Erdman, R.A. and Vandersall, J.H. (1988) Dietary choline effects on milk yield and duodenal choline flow in dairy cattle. J. Dairy Sci., 71: 109-116.

3. Erdman, R.A. and Sharma, B.K. (1991) Effect of dietary rumen - Protected choline in lactating dairy cows. J. Dairy Sci., 74: 1641-1647.

4. Pinotti, L., Baldi, A., Politis, I., Rebucci, R., Sangalli, L. and Dell'Orto, V. (2003) Rumen-protected choline administration to transition cows: Effects on milk production and vitamin E status. J. Vet. Med. A., 50: 18-21.

5. Ardalan, M., Rezayazdi, K. and Banadaky, M.D. (2010) Investigation on the effect of supplementing rumen protected forms of methionine and choline on health situation and reproductive performance of Holstein dairy cows. Pak. J. Biol. Sci., 12(1): 69-73.

6. Cooke, R.F., Rio, N.S.D., Caraviello, D.Z., Bertics, S.J., Ramos, M.H. and Grummer, R.R. (2007) Supplemental choline for prevention and alleviation of fatty liver in dairy cattle. J. Dairy Sci., 90: 2413-2418.

7. Pinotti, L., Campagnoli, A., Orto, V.D. and Baldi, A. (2005) Choline is there a need in the lactating dairy cow. Livest. Prod. Sci., 98: 149-152.

8. Piepenbrink, M.S. and Overton, T.R. (2003) Liver metabolism and production of cows fed increasing amounts of rumen protected choline during the periparturient period. J. Dairy Sci., 86: 1722-1733.

9. Mohsen, M.K., Gaafar, H.M.A., Khalafalla, M.M., Shitta, A.A. and Yousif, A.M. (2011) Effect of rumen protected choline supplementation on digestibility, rumen activity and milk yield in lactating Friesian cows. Slovak $J$. Anim. Sci., 44(1): 13-20.

10. Grummer, R.R. (1993) Etiology of lipid - Related metabolic disorders in periparturient dairy cows. J. Dairy Sci., 76: 3882-3896.

11. Strang, B.D., Bertics, S.J., Grummer, R.R. and Armentano, L.E. (1998) Effect of long-chain fatty acids on triglycerides accumulation, gluconeogenesis, and ureagenesis in bovine hepatocytes. J. Dairy Sci., 81: 728-739.

12. NRC. (2001) Nutrient Requirements for Dairy Cattle. $7^{\text {th }}$ Revised ed. National Academy Press, Washingdon, DC.

13. Sharma, B.K. and Erdman, R.A. (1989) Effects of dietary and abomasally infused choline on milk production responses of lactating dairy cows. J. Nutr., 119: 248-254.

14. Pawar, S.P., Kewalramani, N., Thakur, S.S. and Kaur, J. (2015) Effect of dietary rumen protected choline supplementation on milk choline content in crossbred cows. Indian J. Anim. Nutr., 32(1): 30-35.

15. Hartwell, J.R., Cecavqa, M.J. and Donkin, S.S. (2000) Impact of dietary rumen undegradable protein and rumen-protected choline on intake, peripartum liver triacylglyceride, plasma metabolites and milk production in transition dairy cows. J. Dairy Sci., 83: 2907-2917.

16. Rahamani, M., Dehghan-Banadaky, M. and Kamalyan, R. (2014) Effects of feeding rumen protected choline and Vitamin E on milk yield, milk composition, dry matter intake, body condition score and body weight in early lactating dairy cows. Iran. J Appl. Anim. Sci., 4(4): 693-698.

17. Guretzky, N.A.J., Carlson, D.B., Garrett, J.E. and Drackley, J.K. (2006) Lipid metabolite profiles and milk production for Holstein and jersey cows fed rumen protected choline during the periparturient period. J. Dairy Sci., 89: 188-200.

18. Davidson, S., Hopkins, B.A., Odle, J., Brownie, C., Fellner, V. and Whitlow, L.W. (2008) Supplementing limited methionine diets with rumen - Protected methionine, betaine, and choline in early lactation Holstein cows. J. Dairy Sci., 91: 1552-1559.

19. Zahra, L.C., Duffleld, T.F., Leslle, K.E., Overton, T.R., Putnam, D. and Leblanc, J. (2006) Effects of rumen protected choline and monensin on milk production and metabolism of periparturient dairy cows. J. Dairy Sci., 89: 4808-4818

20. Soltan, M.A., Mujalli, A.M., Mandour, M.A. and Abeer, M.E. (2012) Effect of dietary rumen protected methionine and/or choline supplementation of rumen fermentation characteristics and protective performance of early lactating cows. Pak. J. Nutr., 11(3): 221-230.

21. Garg, M.R., Bhanderi, B.M. and Sherasia, P.L. (2012) Effect of supplementing bypass fat with rumen protected choline chloride on milk yield, milk composition and metabolic profile in crossbred cows. Indian J. Dairy Sci., 65(4): 319-323.

22. Lima, F.S., Filho, M.F.S., Greco, L.F., Susca, F., Magalhaes, V.J., Garrett, J. and Santos, J.E.P. (2007) Effects of feeding rumen-protected choline (RPC) on lactation and metabolism. J. Dairy Sci., 90: 174.

23. Sheikh, F.A., Kewalramani, N. and Thakkur, S.S. (2015) Effect of supplementation of rumen protected lysine plus methionine or choline on blood biochemical parameters in crossbred cows. Indian J. Anim. Nutr., 32(3): 344-347.

24. Nardi, R.D., Marchesini, G., Tenti, S., Contiero, B., Andrighetto, I. and Segato, S. (2012) Lecithin as a supplement for mid - Lactating dairy cows. Acta Agric. Slov., 3(3): 67-70.

25. Baldi, A. and Pinnotti, L. (2006) Choline metabolism in high - Producing dairy cows: Metabolic and nutritional basis. Can. J. Anim. Sci., 86: 207-212.

26. Scheer, W.A., Lucy, M.C., Kerley, M.S. and Spain, J.N. (2002) Effects of feeding soybeans and rumen protected choline during late gestation and early lactation on performance of dairy cows. J. Dairy Sci., 85 Suppl 1: 276.

27. Leiva, T., Cooke, R.F., Brandao, A.P., Marques, R.S. and Vasconcelos, J.L. (2015) Effect of rumen-protected choline supplementation on metabolic and performance responses of transition dairy cows. J. Dairy Sci., 93(4): 1896-1904.

28. Pineda, A. and Cardosa, F.C. (2015) Effects of rumen protected choline with calcium salts of long chain fatty acids on milk yield and milk composition of middle and late lactation Holstein cows. Livest. Sci., 175: 47-58.

29. Sales, J., Homolka, P. and Koukolova, V. (2010) Effect of dietary rumen protected choline on milk production of dairy cows: A meta-analysis. J. Dairy Sci., 93: 3746-3754.

30. Zom, R.L.G., Baal, J.V., Goselink, R.M.A., Bakker, J.A., Veth, M.J. and Vuuren, A.M. (2011) Effect of rumen protected choline on performance, blood metabolites, and hepatic triacylglycerols of periparturient dairy cattle. J. Dairy Sci., 94: 4016-4027.

31. Xu, G., Ye, J.A., Liu, J. and Yu, Y. (2006) Effect of rumen protected choline addition on milk performance and blood metabolic parameters in transition dairy cows. Asian Aust. J. Anim. Sci., 19(3): 390-395.

32. Bindel, D.J., Drouillard, J.S., Titgemeyer, E.C., Wessels, R.H. and Loest, C.A. (2000) Effects of ruminally protected choline and dietary fat on performance and blood metabolites of finishing heifers. J. Anim. Sci., 78(10): 2497-2503.

33. Lima, F.S., Filho, M.F.S., Greco, L.F. and Santos, J.E.P. (2012) Effects of feeding rumen protected choline on incidence of disease and reproduction of dairy cows. Vet. J., 193: 140-145. 
34. Ensink, J. and Kampf, D. (2013) Effect of rumen protected choline chloride in dairy cows. Jahrestagung der Bayrischen Arbeitsgeminschaft Tierenahrung e.V., Freising. p77-80.

35. Suksombat, W., Homkao, J. and Klangnork, P. (2012) Effect of biotin and rumen protected choline supplementation on milk production, milk composition, live weight change and blood parameters in lactating dairy weights. J. Anim. Vet. Adv., 10: 2186-2192.

36. Toghdory, A., Emanuele, S., Ghoorchi, T. and Naserian, A. (2007) Effect of choline and rumen protected choline (Reashure) on milk production, milk composition and blood metabolites of lactating dairy cows. J. Dairy Sci., 90(1): 353.

37. Elek, P., Newbold, J.R., Gaal, T., Wagner, L. and Husveth. F. (2008) Effects of rumen-protected choline supplementation on milk production and choline supply of periparturient dairy cows. Animal, 2(11): 1595-1601.

38. Chung, Y.H., Brown, N.E., Martinez, C.M., Cassidy, T.W. and Varga. G.A. (2009) Effects of rumen protected choline and dry propylene glycol on feed intake and blood parameters for Holstein dairy cows in early lactation. J. Dairy Sci., 81: 2729-2736.

$* * * * * * * *$ 